\author{
С. В. Каденко, В. В. Циганок, О. В. АнАрійчук, О. В. Карабчук \\ Інститут проблем реєстрації інформації НАН України \\ вул. М. Шпака, 2, 03113 Київ, Україна
}

\title{
Аналіз інструментарію піАтримки прийняття рішень у контексті вирішення задач стратегічного планування
}

\begin{abstract}
Наведено огляд наявних програмних засобів і систем підтримки прийняття рішень у слабко структурованих предметних областях з використанням експертної інформації. Наявні засоби проаналізовано та порівняно між собою з позичій їхнього математичного забезпечення та функиійних можливостей, зокрема, з вирішення задач стратегічного планування. Виявлено основні тендениії розвитку інструментарію підтримки прийняття рішень, щуо розроблявся протягом останніх кількох десятиліть. Показано, що наявні засоби автоматизованої підтримки прийняття рішень характеризуються низкою функиійних недоліків та обмежень. На основі проведеного аналізу запропоновано актуальні вимоги до сучасного інструментарію підтримки прийняття рімень. Відповідно до ичих вимог отримано предметні рекомендації щодо вибору засобів підтримки прийняття рішень у процесі стратегічного планування та подальшого удосконалення інструментарію підтримки прийняття рімень.
\end{abstract}

Ключові слова: підтримка прийняття рішень, иільова ієрархічна декомпозиція, стратегічне планування, метод аналізу сценаріїв.

\section{Вступ: актуамьність засобів піАтримки прийняття рішень Амя стратегічного пманування у слабко структурованих предметних областях}

Інструментарій підтримки прийняття рішень 3 використанням експертних знань застосовується, здебільшого, у слабко структурованих предметних областях. Ці області характеризуються низкою ознак, наведених, наприклад, у [1]. Зокрема, йдеться про відсутність одиниць виміру величин, за якими порівнюються об'єкти, високий ступінь невизначеності інформації про предметну область, брак детермінованих даних, складність формального та аналітичного опису, наявність великої кількості взаємопов'язаних факторів впливу, відсутність явно заданої цільової функції. Саме внаслідок наявності цих ознак, часто лише експертні знання

(C) С. В. Каденко, В. В. Циганок, О. В. Андрійчук, О. В. Карабчук 
та методи їхньої обробки дозволяють докладно формально описати слабко структуровану предметну область і надати особі, яка приймає рішення (ОПР), рекомендації, необхідні для того, щоб це рішення було обгрунтованим.

У даній статті основну увагу буде зосереджено на задачах, що пов'язані 3 підтримкою прийняття рішень у процесі стратегічного планування у слабко структурованих предметних областях. Відповідно, побудова стратегій у цих областях, зазвичай, вимагає залучення та обробки експертних знань. Стратегію пропонується розглядати як довгостроковий, послідовний, конструктивний, раціональний, підкріплений ідеологією, стійкий до невизначеності умов середовища план, який супроводжується постійним аналізом та моніторингом у процесі реалізації, і спрямований на досягнення певної головної мети. Невід’ємною складовою стратегічного планування у заданій предметній області має бути побудова адекватної моделі цієї предметної області (наприклад, у вигляді ієрархії факторів впливу [2, 3]). Побудова такої моделі дозволяє ОПР вирішувати цілу низку задач, таких як:

- власне стратегічне планування;

- ранжирування та рейтингування цілей, проектів, факторів, критеріїв, альтернатив;

— оцінка відносної ефективності проектів;

— розстановка пріоритетів у діяльності ОПР;

- розподіл ресурсів між конкретними проектами;

- визначення ефективності потенційних варіантів рішень;

- генерування та аналіз сценаріїв розвитку ситуації тощо.

Для отримання інформації, необхідної для прийняття рішення, в найбільш повному обсязі, ОПР доцільно залучати до процесу не одного експерта, а експертну групу. Рекомендації, сформовані в результаті досягнення консенсусу групою експертів, будуть більш обгрунтованими, аніж поради одного фахівця. 3 огляду на сучасні реалії, бажаною вимогою до інструментарію підтримки прийняття рішень (ППР) є можливість організації групової роботи експертів у віддаленому режимі (через мережу).

Високий рівень складності та невизначеності слабко структурованих предметних областей, необхідність застосування міждисциплінарних підходів, врахування великої кількості неоднорідних факторів впливу та думок багатьох експертів 3 різних галузей (які, у загальному випадку, працюють дистанційно), вимагає автоматизації процесу ППР, зокрема, під час стратегічного планування. Сучасні засоби та системи підтримки прийняття рішень (СППР) покликані спростити та водночас удосконалити процес збору та обробки експертної інформації з метою їі максимально повного використання. Якщо інформація, що отримана від експертів, $\epsilon$ повною, узгодженою, детальною, якщо вона не спотворюється в процесі збору та обробки, то рекомендації для ОПР, сформовані на її основі, стають більш достовірними, а відповідні рішення — краще обгрунтованими.

У рамках даної статті, для аналізу можливостей сучасного інструментарію СППР, пропонується взяти за основу широко апробовану технологію стратегічного планування, описану, зокрема, у [4]. Технологія включає наступні концептуальні етапи: 
1) постановка головної мети стратегічного плану ОПР у заданій предметній області та формування експертної групи (наприклад - 3 використанням мереж співавторства [5]);

2) ієрархічна декомпозиція експертами головної мети, тобто, побудова ієрархії факторів її досягнення. Декомпозиція відбувається до рівня конкретних проектів - атомарних факторів, на які в змозі впливати ОПР;

3) оцінка експертами відносного впливу кожного з факторів ієрархії (peзультатом даного етапу є база знань (Б3) СППР про предметну область у контексті головної мети стратегічного плану, представлена у вигляді зваженого графа);

4) визначення розподілу наявних обмежених ресурсів між проектами, який дозволяє досягти найвищого ступеня виконання поставленої стратегічної мети; розрахунок цього показника виконується на заданий момент часу, з урахуванням поточного впливу факторів і граничних обсягів фінансування проектів.

Зазначена технологія продемонструвала ефективність у таких прикладних сферах як:

— планування розвитку оборонної сфери [4];

- побудова стратегії розвитку та оцінка ефективності заходів у сфері космічної діяльності та виробництва космічної техніки України [6];

— планування у сфері охорони довкілля [7];

— дослідження інформаційних операцій [8];

— побудова і аналіз сценаріїв розвитку подій $[9,10]$.

На користь технології свідчить також і те, що для вирішення задач стратегічного планування у слабко структурованих предметних областях, зарубіжні розробники інструментарію ППР керуються аналогічними підходами [11].

Слід зазначити, що будь-який інструментарій автоматизованої ППР має свої передумови створення та початкове цільове призначення. Через це важко виділити єдиний спільний критерій, за яким можна було би порівнювати між собою усі без винятку програмні продукти для ППР. У даній статті пропонується розглянути можливості найбільш відомих засобів з позицій їхньої придатності для вирішення задач, що виникають під час стратегічного планування у слабко структурованих предметних областях із використанням експертної інформації.

\section{Анамітичний огмяА поширених інструментів ППР}

У зв'язку зі стрімким зростанням застосування технологій ППР останнім часом спостерігається також зростання попиту на інтелектуальні системи, призначені для розв'язання задач ППР. Серед світових розробок СППР останніх років слід згадати: ExpertChoice, SuperDecisions, DecisionLens, D-Sight, Promethee, ОЦЕНКА И ВЫБОР, СОЛОН, Консенсус та їхні модифікації.

Спільні риси, що характеризують усі архітектури СППР, незалежно від призначення - наступні: наявність Б3, наявність моделі предметної області (контексту рішення та критеріїв оцінки), наявність користувацького інтерфейсу [12]. 3 огляду на міркування, викладені у вступі, зосередимо увагу на СППР універсального призначення, математичне забезпечення яких включає найбільш популярні сучасні методи прийняття рішень. 


\section{СППР SuperDecisions та ії аналоги}

Один із найбільш поширених на сьогоднішній день метод підтримки прийняття рішень - метод аналізу ієрархій і мереж, розроблений Сааті [2], реалізований, зокрема, у СППР SuperDecisions [13]. Ця комп'ютерна система прийшла на зміну відомому у недалекому минулому програмному продукту ExpertChoice [14]. Система призначена для розрахунку відносної ефективності (вагомості) альтернатив на основі їхньої багатокритеріальної оцінки. Граф ієрархії критеріїв у загальному випадку включає чотири підграфи: переваги (B - benefits), можливості (O - opportunities), витрати (C - costs) та ризики (R - risks).

Ваги кожної із наявних альтернатив і важливість критеріїв визначаються експертами шляхом парних порівнянь у фундаментальній шкалі, або безпосереднього оцінювання. Після цього, оцінки агрегуються методом зваженої суми. Оцінки за критеріями, що відповідають перевагам і можливостям беруться зі знаком плюс, а оцінки за критеріями, що визначають витрати та ризики - зі знаком мінус.

Діапазон конкретних сфер прикладного застосування системи дуже широкий. У цьому можна переконатися, переглянувши тези доповідей міжнародного симпозіуму з методу аналізу ієрархій за останні кілька десятиліть (1988-2018) [15].

SuperDecisions $\epsilon$ лише однією із багатьох СППР, в основі якої лежать методи аналізу ієрархій і мереж. 3-поміж інших СППР, у яких реалізовані ці методи, варто згадати такі системи як DecisionLens, ExpertChoice, MakeItRational, MindDecider, RationalFocalPoint (RFP), SmarterGovernment. При цьому, лише в системі DecisionLens, реалізований цикл стратегічного планування, про який йшлося у вступі (вартість ліцензії на систему DecisionLens - 25000-30000 євро, пробна версія відсутня). Інші системи зосереджені на ранжируванні та побудові рейтингів варіантів рішень за агрегованим критерієм.

Отже, у системі SuperDecisions і більшості ऑï аналогів, фактично, реалізовані лише окремі етапи технології стратегічного планування. Система DecisionLens, у якій реалізований розподіл ресурсів, внаслідок великої вартості, не є доступною для широкого застосування. Також, більшість систем мають обмеження у сфері віддаленої роботи експертів.

\section{CППР PROMETHEE Visual}

Дана СППР, як і розглянута у попередньому пункті, призначена для побудови ранжирування варіантів рішень (альтернатив) на основі їхніх оцінок за кількома критеріями. Система та метод PROMETHEE (у перекладі на українську ця абревіатура розшифровується як «метод організації ранжирування переваг для збагачення оцінок»), який лежить в іії основі, розроблені бельгійськими вченими та описані в [16]. Promethee Visual $є$ «нащадком» попередніх продуктів, де було реалізовано відповідний метод, таких як PromCalc та DecisionLab.

Агрегація оцінок здійснюється методом зваженої суми. Критерії можуть бути якісними або кількісними. Оцінки можуть бути абсолютними та відносними. Особливість методу — наявність так званої «функції переваги» (звичайна, Uподібна, V-подібна, Гаусівська, ступінчаста), яка задає характер відношення переваги залежно від значень одного чи кількох визначальних параметрів. 
Відповідно, система дозволяє вирішити лише окремі задачі з циклу стратегічного планування, описаного вище. Набір реалізованих у ній функцій не передбачає розподілу ресурсів, а також організації дистанційних експертиз.

\section{СППР 1000minds}

1000minds [17] - інструмент для групового, у загальному випадку, дистанційного прийняття рішень з ранжирування альтернатив на основі їхніх оцінок за кількома (двома або більше) критеріями. Система не передбачає завантаження програмного забезпечення на індивідуальні робочі місця експертів - уся робота 3 підтримки прийняття рішень відбувається в мережі.

В основі математичного забезпечення системи лежить метод PAPRIKA (PotentiallyAllPairwiseRanKingsofallpossibleAlternatives), тобто, метод усіх потенційних попарних ранжирувань усіх можливих альтернатив, описаний, зокрема, у [18]. У процесі експертизи експертам пропонується попарно ординально порівнювати альтернативи із заданої множини (відповідати на питання: «яка з двох запропонованих альтернатив краща?»). При цьому, зазвичай, йдеться про досягнення компромісу між кількома критеріями. Наприклад, експерту пропонується обрати високовартісний але перспективний проект, або менш перспективний проект 3 нижчою собівартістю. Критеріїв може бути не два, а більше. Порядок парних порівнянь - такий, щоб мінімізувати кількість звернень до експерта; велика кількість значень ординальних парних порівнянь відновлюється за транзитивністю, на основі наявних відповідей експерта. Кінцевим результатом експертизи є рейтинг та ранжирування альтернатив.

Як бачимо, у даній системі основну увагу зосереджено не перших етапах процедури стратегічного планування, описаної у вступі. Бракує функцій розподілу ресурсів і віддаленого режиму групової експертизи.

\section{CППР AIRM online}

СППР «AIRM online» фактично являє собою програмну реалізацію методу AIRM (aggregated indices randomization method), тобто, рандомізації агрегованих індексів. Опис методу можна знайти, зокрема, у [19]. Метод розроблений з огляду на невизначеність, яка виникає під час оцінки вагових коефіцієнтів: інформація про ваги критеріїв та альтернатив (об’єктів) часто задана у вигляді не чисельних, а ординальних або інтервальних оцінок. Такої інформації недостатньо для однозначного задання вагових коефіцієнтів. Значення вектору ваги обирається на основі Баєсівської рандомізації із множини всіх можливих значень, які можуть приймати його координати. Вважається, що кожна координата $є$ рівномірно розподіленою на певному чисельному проміжку, i, відповідно, агрегований показник якості об'єктів $Q$, що порівнюються за кількома критеріями, також є випадковою величиною. Його значення визначається як математичне сподівання цієї величини, а точність характеризується стандартним відхиленням показника.

Отже, дана система орієнтована на окремий вид оцінок і дозволяє вирішувати лише задачі окремого класу — визначення ваг альтернатив (це лише один 3 етапів технології стратегічного планування). 


\section{СППР Analytica}

У візуальному програмному пакеті «Аналітика», розробленому компанією Lumina Decision Systems [20], для ілюстративного подання ситуації, що вимагає прийняття рішення, використовуються так звані діаграми впливів.

Слід зазначити, що математичне забезпечення системи грунтується не на якихось конкретних методах багатокритеріальної підтримки прийняття рішень, а, здебільшого, на статистичному інструментарії. Значна увага приділяється побудові функцій розподілу ймовірностей величин, що характеризують альтернативні варіанти рішення.

Система не дозволяє вводити оцінки у вигляді парних порівнянь - від експерта вимагається, щоб він вводив одиниці виміру, діапазони, граничні значення величин, що впливають на досягнення цілі.

Таким чином, пакет Analytica має беззаперечну перевагу - можливість задання шкали оцінювання в процесі експертизи самим експертом. Утім, у ньому реалізовані лише окремі етапи циклу стратегічного планування.

\section{CППР D-Sight}

Програма D-Sight [21] призначена для багатокритеріального оцінювання (ранжирування) множини альтернатив із використанням різних шкал (кількісних та якісних). Слід відзначити цікаву можливість формування експертом власної шкали, такої як, наприклад, шкала професійних навичок. Під час експертизи, як i в більшості інших СППР, можна задавати значення оцінок альтернатив і ваг критеріїв. У програмі передбачено багато засобів візуалізації результатів, зокрема, 3 використанням інструментарію методу PROMETHEE/GAIA та елементів багатофакторної теорії корисності (MAUT).

Отже, система, як і попередня, має певні переваги, що пов'язані з вибором шкал оцінювання, але не реалізує весь цикл стратегічного планування, та не пристосована для віддаленої роботи групи експертів.

\section{СППР MakeItRational}

Ще одна СППР, де реалізований метод аналізу ієрархій - MakeItRational [22]. Система призначена для багатокритеріального оцінювання та вибору альтернатив із заданої множини. Спочатку вводиться множина альтернатив, потім глобальний критерій оцінювання, після цього - ієрархія його підкритеріїв, що відображають як негативні, так і позитивні впливи (витрати та вигоди). На наступному етапі альтернативи оцінюються за критеріями, при чому оцінки можна задавати безпосередньо, у вигляді чисельних значень, або ж у вигляді парних порівнянь у фундаментальній шкалі Сааті. Кінцевим результатом експертизи є рейтинг альтернатив за глобальним критерієм і його підкритеріями. У системі передбачені можливості експортування результатів у MS Excel та автоматичного формування документа із заключним звітом про результати експертизи.

Таким чином, як і в пакеті SuperDecisions, у системі MakeItRational основну увагу приділено задачам рейтингування альтернатив. Отримані рейтинги можуть служити підставою для подальшого стратегічного планування, але функції розподілу ресурсів у системі не реалізовані. 


\section{СППР MindDecider}

СППР MindDecider [23], як і інші системи, вже наведені в даному огляді, призначена для багатокритеріального оцінювання та побудови рейтингів альтернатив. Експертиза поділяється на декілька етапів, кожному з яких відповідає певний режим роботи: планування та дизайн, оцінювання, аналіз за часом, формування звіту. Спочатку формується головна ціль, потім - множина альтернатив, критерії оцінки та діапазони значень оцінок. Далі проводиться оцінювання альтернатив за критеріями. Після агрегування оцінок альтернатив за окремими критеріями будується їхній глобальний рейтинг (виражений у відсотках) і глобальне ранжирування.

Отже, подібно до більшості вже згаданих систем, MindDecider не дозволяє автоматизувати весь цикл стратегічного планування.

\section{СППР LogicalDecisions}

СППР Logical Decisions [24] використовує інструментарій методу аналізу ієрархій і багатофакторної теорії корисності (MAUT). Система призначена для багатокритеріальної оцінки альтернатив із заданої множини. Ваги критеріїв («measures») задаються шляхом безпосереднього оцінювання, або парних порівнянь у довільній шкалі. Альтернативи оцінюються попарно, знов-таки, у довільній шкалі. Отже, у Logical Decisions реалізовані лише окремі етапи згаданої технології стратегічного планування.

\section{СППР TreeAgePro}

СППР Tree Age Pro [25] призначена для оцінки різних варіантів рішень. Можливі варіанти представляються у вигляді гілок дерева рішень. Граф дерева рішень (подібно до діаграми впливів у системі Analytica) може включати вершини різних типів: «шанс» (імовірнісну вершину), «марковську вершину», «вершинурішення», «вершину, що відповідає логічній змінній» та ін. Фактично, TreeAgePro, знов-таки, подібно, до системи Analytica, являє собою ціле середовище з широкими можливостями для автоматизації і структурування процесу експертного оцінювання та вибору під час вирішення задач різноманітної специфіки. Втім, інструментарій, що лежить в основі математичного забезпечення системи, грунтується, здебільшого, на апараті теорії імовірностей. Ще раз підкреслимо, що пакети TreeAgePro та Analytica мають широкі можливості для адаптації до конкретних задач, але відповідні функції потребують окремої реалізації.

\section{CППР RFP (RationalFocalPoint)}

RFP (Rational Focal Point) [26] — комплекс засобів для автоматизації процесу підтримки прийняття рішень на муніципальному рівні. Зокрема, йдеться про рішення щодо фінансування різноманітних проектів, портфельного інвестування, та ін. Варіанти рішення оцінюються за кількісними та якісними критеріями. Система передбачає виконання як парних порівнянь, так і безпосереднього експертного оцінювання. Очевидно, що, оскільки йдеться про рішення масштабу міста, слід враховувати велику кількість факторів, впливи яких змінюються у часі, а також, думки багатьох експертів, які, у загальному випадку, працюють у дистанцій- 
ному режимі. Отже, розробники системи (спочатку — компанія IBM, пізніше Unicom) зробили наголос на мережевому режимі роботи системи та на можливостях «програвання» варіантів рішення у часі. Таким чином, можливість віддаленої роботи у системі є іiі беззаперечною перевагою, але вузьке цільове призначення дещо обмежує іiі функційні можливості.

\section{СППР VeryGoodChoice}

Програма Very Good Choice [27] (яка дещо застаріла з точки зору застосованих програмних рішень і більше не супроводжується розробниками) створена компанією MVLsoft, використовує як базовий метод підтримки прийняття рішень метод ELECTRE (Elimination Et Choix Traduisant la Realite - виключення та вибір, що відображають реальність) [28]. Програма виконана у вигляді «надбудови» (add-in) для пакету Microsoft Excel. Можливості системи в розрізі стратегічного планування - обмежені.

\section{СППР «ОЦЕНКА И ВЫБОР»}

«ОЦЕНКА И ВЫБОР» - інтернет-базована програмна система, призначена для вирішення задач багатокритеріального прийняття рішень. Ці задачі можуть бути ієрархічно структуровані (від критеріїв верхнього рівня до критеріїв нижнього: Мета аналізу - Узагальнені показники - Показники). «ОЦЕНКА И ВЫБОР» використовує різноманітні методи підтримки прийняття рішень: Метод аналізу ієрархій Т. Сааті (MAI), функції цінності, метод простого зважування, домінантний аналіз Парето, аналіз ВИГОДИ/ВИТРАТИ.

Кінцевий результат експертизи - рейтинги альтернатив, розраховані як зважені суми відповідних показників, що характеризують ці альтернативи. Показники можуть бути якісними, кількісними, логічного типу (так/ні).

Варто наголосити, що система апріорно орієнтована на дистаниійне вирішення задач підтримки прийняття рішень.

Таким чином, дистанційну роботу та використання різних типів оцінок можна віднести до основних переваг системи. Втім, власне, визначення оптимальної стратегії, залишається поза межами ії можливостей.

Детальніше з описом можливостей і процесу функціонування системи можна ознайомитися в $[29,30]$.

\section{Інструментальна система «СВИРЬ»}

Згідно з авторським описом, «СВИРЬ» $є$ інструментальною системою, що призначена для вирішення задач багатокритеріального вибору. Вона відповідає таким вимогам як: універсальність, можливість одночасного використання об'єктивних і суб'єктивних оцінок, розв'язання задач високої розмірності, автономність у вирішенні задач, можливість комплексування з іншими системами для обміну даними та їхньої обробки, ергономічність, здатність до розвитку.

Задачі багатокритеріального вибору розв'язуються у системі методами багатокритеріальної оптимізації і класифікації, аналізу ієрархій. Ваги критеріїв оцінки об’єктів задаються безпосередньо, обчислюються на основі матриць парних порів- 
нянь на основі переваг, заданих експертами, або обчислюються на основі рівноцінності ознак у таблицях чи рівноцінності первинних ознак.

Результати представляються в єдиній кольоровій шкалі якості з можливістю iii настроювання та збереження. На виході система також дозволяє отримати графіки розподілу об'єктів за критеріями та за загальною оцінкою та проаналізувати вклад критеріїв до загальної оцінки (провести так званий аналіз чутливості).

Отже, перевагами системи є можливість задавання оцінок у різних шкалах та графічне представлення результатів експертизи. Якщо говорити про побудову стратегій, то певні етапи технології стратегічного планування (розподіл ресурсів) потребують окремої реалізації, або підключення додаткових модулів. 32].

Система та їі модифікації описані у численних публікаціях, зокрема у [31,

\section{СППР «Солон-3» та «Консенсус-2»}

СППР типу «Солон-3» $є$ інструментом підтримки прийняття рішень шляхом формування комплексних цільових програм (КЦП). КЦП являє собою сукупність заходів, що об'єднані глобальною ціллю та спільними ресурсами. Основні задачі, що виникають під час формування КЦП наступні:

1) формулювання головної цілі;

2) визначення перспективних напрямків її виконання (підцілей);

3) відбір найефективніших засобів (проектів);

4) розподіл ресурсів між відібраними проектами.

Для вирішення задач 2) та 3) виникає потреба у ранжируванні об'єктів (проектів, цілей).

Технологічний процес підтримки прийняття рішень за допомогою СППР «Солон-3» [33], включає наступні етапи: декомпозиція головної цілі та побудова ієрархії цілей, (експертне) визначення часткових коефіцієнтів впливу підцілей, визначення (розрахунок) відносної ефективності напрямків виконання програми та генерація альтернативних проектів, розрахунок коефіцієнтів впливу проектів на досягнення головної цілі, що використовуються як показники відносної ефективності проектів. Для розрахунку відносної ефективності проектів у даній СППР застосовується метод цільового динамічного оцінювання альтернатив (МЦДОА).

Детальний опис роботи СППР «Солон-3» можна знайти у [3].

Система розподіленого збору експертної інформації (СРЗЕО) «Консенсус-2» $[34,7]$ була розроблена та реалізована для спрощення процесу проведення групових експертиз у віддаленому режимі. Система являє собою хмарне рішення; вона дозволяє членам експертної групи віддалено долучатися до експертизи, покликаної вирішити конкретну задачу, та проводити групову декомпозицію цієї задачі. Інтерфейс системи суттєво полегшує вирішення задачі 2) з вищенаведеного переліку групою експертів. Для розподілу ресурсів між проектами необхідно підключати додаткові модулі.

\section{Інші програмні продукти та застосунки для підтримки прийняття рімень}

Унаслідок великого попиту з боку представників різних прикладних сфер та індустрій, наявне ПЗ для ППР постійно вдосконалюється. Водночас, триває про- 
цес розробки нових програмних продуктів як у вигляді окремих рішень, так і у вигляді надбудов і застосунків. Пересвідчитися у цьому дозволяють переліки відповідних рішень, що наводяться на сайтах продавців (онлайн-ринках) ПЗ. Так, наприклад, на платформі Capterra [35], окрім уже згаданих СППР 1000minds, DecisionLens, Analytica, ExpertChoice, можна побачити десятки інших програмних продуктів і цілих платформ, кожна 3 яких характеризується специфічним способом реалізації і цільовим призначенням у конкретних предметних областях (підтримка клієнтів (Zingtree), візуалізація складних ситуацій для групового прийняття рішень у великих організаціях (EIDOS) та ін.).

Утім, слід зазначити, що поняття decision support software у розумінні учасників подібних онлайн-ринків стало більш широким. Наприклад, програмний продукт Wolfram Mathematica (також доступний на платформі Capterra) - хмарне рішення (фактично, ціле середовище), призначене для розпізнавання образів, візуалізації даних та інших функцій, з використанням машинного навчання, нейронних мереж, дата-майнінгу та інших технологій — також класифікується як decision support software.

До того ж, критерії, за якими порівнюються програмні інструменти, зміщено в бік їхньої комерційної привабливості. Наприклад, на вищевказаній платформі Capterra перелік характеристик продукту наступний: початкова ціна, наявність безкоштовної або пробної версії, спосіб реалізації (хмарне рішення, веб-застосунок, iOS/Windows/Android, мобільний додаток тощо), необхідне навчання для користувачів (онлайн-курс, документація, вебінари тощо) і технічна підтримка (у робочі години, цілодобово онлайн тощо). При цьому, майже не приділяється уваги розгляду (аналізу) конкретних математичних і технологічних рішень, які покладені в основу того чи іншого інструменту ППР. Відтак, важко розглядати відповідні інструменти в порівняльному контексті, особливо з позицій науковця, а не користувача-початківця з конкретним вузько-орієнтованим запитом.

Слід зазначити, що прив'язка програм і застосунків для ППР до специфічних вузьких задач та окремих предметних областей, скоріш за все, продиктована комерційними інтересами, суттєво обмежує можливості їхнього застосування. Очевидно, що, з точки зору користувачів, СППР має бути універсальною, але допускати можливість адаптації до конкретних прикладних задач у кожній предметній області (наприклад, шляхом декомпозиції цих задач) і швидкого коригування моделей предметних областей. У протилежному випадку доведеться щоразу застосовувати окрему СППР для кожної предметної області, чи конкретної задачі.

У $[36,37]$ наведено порівняльний аналіз деяких СППР, зокрема, не згаданих у даному огляді.

Взявши за основу зроблений у даній роботі аналіз і доповнивши його інформацією про деякі інші СППР з [36, 37], отримано зведені дані про системи у розрізі застосованих математичних і технологічних рішень (див. таблицю).

Окрім можливостей вибору шкал оцінки альтернатив (парних порівнянь та інших), організації групового оцінювання та організації роботи в мережі (через веб-версію програми), для підвищення обгрунтованості рішень (зокрема, і стратегічних) визначальними є і деякі інші функційні можливості СППР. До них належать урахування часових затримок у реалізації окремих компонентів стратегічної 
цілі, а також автоматизований аналіз чутливості кінцевого рейтингу або ранжирування варіантів рішень до збурень вхідних даних.

Порівняння можливостей сучасних СППР

\begin{tabular}{|c|c|c|c|c|c|c|c|}
\hline Назва СППР & 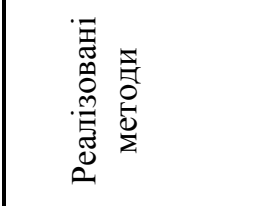 & 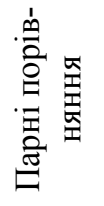 & 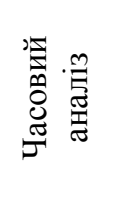 & 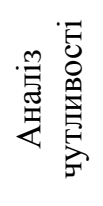 & 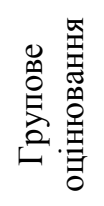 & 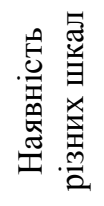 & 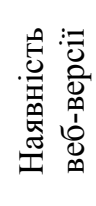 \\
\hline 1000Minds & PAPRIKA & Так & $\mathbf{H i}$ & Так & Так & $\mathbf{H i}$ & Так \\
\hline AIRM Online & AIRM & $\mathbf{H i}$ & $\mathbf{H i}$ & Так & Hi & Hi & Так \\
\hline Analytica & & Hi & Так & Так & Hi & Hi & Так \\
\hline DecisionLab & & Так & $\mathbf{H i}$ & Так & Hi & $\mathbf{H i}$ & Hi \\
\hline DecisionLens & AHP, ANP & Так & & Так & Так & & Так \\
\hline D-Sight & $\begin{array}{l}\text { MAUT, } \\
\text { PROMETHEE }\end{array}$ & Так & $\mathbf{H i}$ & Так & Так & $\mathbf{H i}$ & Так \\
\hline ExpertChoice & AHP & Так & Hi & Так & Так & $\mathbf{H i}$ & Так \\
\hline LogicalDecisions & AHP, MAUT & Так & $\mathbf{H i}$ & Так & Так & $\mathbf{H i}$ & Hi \\
\hline MakeItRational & AHP & Так & Hi & Так & Так & Hi & Так \\
\hline MindDecider & AHP & $\mathbf{H i}$ & Так & Так & Так & Hi & $\mathbf{H i}$ \\
\hline $\begin{array}{l}\text { PROMETHEE } \\
\text { Visual }\end{array}$ & PROMETHEE & Так & $\mathbf{H i}$ & Так & Так & Так & Hi \\
\hline RFP & AHP, ANP & Так & Так & Так & Так & $\mathbf{H i}$ & Так \\
\hline SuperDecisions & AHP, ANP & Так & $\mathbf{H i}$ & Так & Hi & $\mathbf{H i}$ & $\mathbf{H i}$ \\
\hline TreeAgePro & & Hi & $\mathbf{H i}$ & Так & Hi & Hi & Hi \\
\hline VeryGoodChoice & ELECTRE & Так & $\mathbf{H i}$ & Так & Так & $\mathbf{H i}$ & $\mathbf{H i}$ \\
\hline $\begin{array}{l}\text { ОЦЕНКА И } \\
\text { ВЫБОР }\end{array}$ & $\begin{array}{l}\text { АНР, ФЦ, } \\
\text { ПареттоАн }\end{array}$ & Так & Hi & & Так & $\mathbf{H i}$ & Так \\
\hline СВИРЬ & $\begin{array}{l}\text { БКОпт, Класиф, } \\
\text { АНР }\end{array}$ & Так & $\mathbf{H i}$ & Так & Так & & $\mathbf{H i}$ \\
\hline СОЛОН & МЦДОА & Так & Так & Так & Так & Так & Так \\
\hline
\end{tabular}

Наведений огляд у жодному разі не можна вважати вичерпним, однак він ілюструє найбільш загальні тенденції у розвитку сучасних СППР, що використовують експертні оцінки (зокрема, задані у вигляді парних порівнянь і в інших шкалах). 
Зазначимо, що жодна 3 перелічених систем не дозволяє організувати весь цикл стратегічного планування (наведений у вступі) з використанням експертної інформації у віддаленому режимі. Так, наприклад система DecisionLens (одна із найдорожчих СППР у світі) об'єднує найбільшу кількість функцій, необхідних для стратегічного планування (в тому числі, розподіл ресурсів). Втім, вона має обмеження, що стосуються віддаленої роботи експертів і вибору шкал експертного оцінювання. Системи 1000minds, RFP, «ОЦЕНКА И ВЫБОР» призначені для дистанційної роботи експертів, але зосереджуються, здебільшого, на задачах побудови рейтингів і ранжирувань альтернатив. Системи D-Sight та PROMETHEE Visual пропонують широкі можливості щодо вибору шкал оцінювання, але мають обмеження щодо роботи експертів у дистанційному режимі. Розроблені авторським колективом СППР «Солон» та «Консенсус-22 зі спеціальними «надбудовами» для агрегації оцінок, заданих у різних шкалах, і визначення оптимального (з точки зору максимізації ступеня досягнення стратегічної мети) розподілу ресурсів, лише у сукупності дозволяють охопити весь процес стратегічного планування та відповідний спектр задач. При цьому окремі аспекти потребують доопрацювання та удосконалення.

На основі наведеного огляду ОПР організатор експертизи чи інженер знань можуть обирати інструментарій ППР залежно від задач, які покликана розв'язати конкретна експертиза.

\section{Інші аспекти та напрями удосконалення інструментарію ППР}

На наш погляд, існують і інші, вкрай важливі аспекти процесу ППР, які залишилися поза увагою представленого огляду, що потребують врахування під час удосконалення наявного та розробки нового інструментарію ППР. Наведемо їхній стислий перелік.

1. Визначення відносної компетентності експертів під час проведення групових експертиз. Для визначення відносної компетентності експертів у кожному питанні, що розглядається, слід враховувати кілька складових: об'єктивну компоненту, взаємну оцінку та самооцінку членів експертної групи, а також якість інформації, наданої експертом у ході конкретної експертизи [38].

2. Урахування особливостей роботи з експертами [39], зокрема: психофізіологічних обмежень людини [40], вимоги перебування оцінок альтернатив із заданої множини в межах одного порядку, визначення необхідної кількості порівнянь, які необхідно виконати (якщо оцінки задаються шляхом парних порівнянь) [41], можливостей зміни послідовності пред'явлення альтернатив експертам для оцінювання [42].

3. Можливість організації зворотного зв'язку з експертами з метою підвищення якості (узгодженості, повноти, детальності) експертної інформації [38].

4. Можливість врахування у СППР не лише експертної, а й іншої інформації, зокрема, отриманої на основі даних з доступних джерел [43]. Зазначена можливість напряму залежить від рівня розвитку засобів обробки природної мови (NLP), що використовуються для ППР.

5. Можливість аналізу сценаріїв розвитку подій за умов змін впливу тих чи інших факторів. В основу сценарного аналізу можна покласти принципи аналізу чутливості. 


\section{Висновки}

Наведено стислий огляд і проведено порівняльний аналіз наявних засобів ППР з позицій їхньої придатності для вирішення задач стратегічного планування у слабко структурованих предметних областях.

Показано, що жодна автоматизована СППР з тих, що розглядалися, не дозволяє вирішувати весь комплекс задач, що виникають у процесі стратегічного планування на основі експертної та іншої інформації. Запропоновано низку предметних вимог до сучасних засобів ППР. Отримано перелік рекомендацій щодо вибору програмних засобів для розв'язання задач, пов'язаних з ППР у ході стратегічного планування, а також щодо удосконалення наявних і розробки нових СППР.

Незважаючи на збільшення обсягів наявних відкритих даних, які можуть використовуватися для ППР, актуальність задач отримання та обробки експертної інформації, і особливо експертних знань, зростає. Відповідно, релевантною лишається проблема розробки та вдосконалення засобів ППР, які дозволяють отримувати та обробляти як експертну, так і іншу інформацію в максимально повному обсязі та без спотворень.

Найбільш актуальними напрямками подальших досліджень за тематикою статті є розширення можливостей засобів ППР щодо організації дистанційної роботи експертів та обробки даних про предметну область з усіх доступних джерел.

1. Таран Т.А., Зубов Д.А. Искусственный интеллект. Теория и приложения. Луганск: ВНУ им. В. Даля, 2006.

2. Saaty T.L. Decision Making with Dependence and Feedback: The analytic Network Process. Pittsburgh, RWS Publicaitons, 1996.

3. Тоценко В.Г. Методы и системы поддержки принятия решений. Алгоритмический аспект. ИПРИ НАНУ. Киев: Наук. думка. 2002.

4. Циганок В.В., Каденко С.В., Андрійчук О.В., Качанов П.Т., Роїк П.Д. Інструментарій підтримки прийняття рішень як засіб стратегічного планування. Озброєння та військова техніка. 2015. № 3(7). C. 59-66.

5. Balagura I., Kadenko S., Andriichuk O., Gorbov I. Defining Potential Academic Expert Groups based on Joint Authorship Networks Using Decision Support Tools. Selected Papers of the XIX International Scientific and Practical Conference on Information Technologies and Security (ITS 2019) Kyiv, 2019. P. 222-233.

6. Tsyganok V.V., Kadenko S.V., Andriichuk O.V. Using Different Pair-wise Comparison Scales for Developing Industrial Strategies. Int. J. Management and Decision Making. 2015. Vol. 14. No 3. P. 224-250.

7. Tsyganok V., Kadenko S., Andriichuk O., Roik P. Usage of multicriteria decision-making support arsenal for strategic planning in environmental protection sphere. Journal of Multi-criteria Decision Analysis. 2017. 24(5-6). P. 227-238.

8. Dodonov A., Lande D., Tsyganok V., Andriichuk O., Kadenko S., Graivoronskaya A. Information Operations Recognition. From Nonlinear Analysis to Decision-Making. Lambert Academic Publishing, 2019.

9. Згуровський М.3. Сценарний аналіз як системна методологія передбачення. Системні дослідження та інформаційні технології. 2002. № 1. С. 7-38.

10. Подберезкин А.И. Вероятный сценарий развития международной обстановки после 2021 года. Москва: МГИМО-Университет, 2015.

11. Applications and Theory of Analytic Hierarchy Process. Decision Making for Strategic Decisions. De Felice, F. (Ed.). IntechOpen, 2016. 
12. Powe D.J. Decision support systems: concepts and resources for managers. Westport, Conn., Quorum Books, 2002.

13. Super Decisions. URL: http://www.superdecisions.com/

14. Expert Choice Desktop: Powerful Performance for Organizational Decision-Making. URL: http://expertchoice.com/products-services/expert-choice-desktop

15. ISAHP proceedings. URL: http://www.isahp.org/proceedings/

16. Mareschal B., Brans J.-P. «PROMETHEE Methods», Ch 5 in: Figueira, J., Greco, S., and Ehrgott, M., eds., Multiple Criteria Decision Analysis: State of the Art Surveys Series / New York: Springer, 2005

17. Decision-making Support System «1000minds». URL: http://www.1000minds.com/

18. Hansen P.,Ombler F. A new method for scoring multi-attribute value models using pairwise rankings of alternatives. Journal of Multi-Criteria Decision Analysis. 2008. 15. P.87-107.

19. Hovanov N., Yudaeva M., Hovanov K. Multicriteria estimation of probabilities on basis of expert non-numeric, non-exact and non-complete knowledge. European Journal of Operational Research. 2009. Vol. 195. Issue 3. P. 857-863.

20. Decision-making Support System «Analytica». URL: https://lumina.com/products/free101/

21. Decision-making Support System «D-sight». URL: http://www.d-sight.com/

22. Decision-making Support System «MakeItRational». URL: http://makeitrational.com/

23. Decision-making Support System «MindDecider». URL: http://www.minddecider.com/

24. Decision-making Support System «Logical Decisions». URL: http://www.logicaldecisions.com/

25. Decision-making Support System «Tree Age Pro». URL: http://www.treeage.com

26. Decision-making Support System «RFP» (Rational Focal Point). URL: https://www.teamblue.unicomsi.com/products/focal-point/

27. Decision-making Support System «Very Good Choice». URL: https://mvlsoft-very-goodchoice-add-in-for-exce.software.informer.com/download/

28. Roy B. Classement et choix en présence de points de vue multiples (la méthode ELECTRE). La Revue d'Informatique et de Recherche Opérationnelle (RIRO). 1968. No. 8. P. 57-75.

29. Информационно-аналитическая система «ОЦЕНКА И ВЫБОР». URL: http://www.deol.ru/users/DecisionSupporter/projects/iasctc.html

30. Demo Project - Compare car models 2001-2012 / ESTIMATION \& CHOICE. URL: http://decisionsupporter.com/Projects.asp

31. Микони С.В. Система выбора и ранжирования СВИРЬ. Труды междунар. конгресса «Искусственный интеллект в XXI веке». Дивноморское 3-8.09.2001. Москва: Физматгиз, 2001. Том 1. С. 500-507.

32. Микони С.В., Бураков Д.П., Сорокина М.И. Реализация принципов эргономичности и интеллектуальности в системе СВИРЬ. Программные продукты и системыл. 2002. № 3. С. 28 -32.

33. Свідоцтво про державну реєстрацію авторського права на твір №8669. Міністерство освіти і науки України державний департамент інтелектуальної власності. Комп’ютерна програма «Система підтримки прийняття рішень СОЛОН-3» (СППР СОЛОН-3) / Тоценко В.Г., Качанов П.Т., Циганок В.В. Зареєстровано 31.10.2003.

34. Свідоцтво про реєстрацію авторського права на твір № 75023. Комп’ютерна програма «Система розподіленого збору та обробки експертної інформації для систем підтримки прийняття рішень - «Консенсус-2» / Циганок В.В., Роїк П.Д., Андрійчук О.В., Каденко С.В. Від 27/1 1/2017.

35. Best Decision Support Software 2020 Reviews of the Most Popular Tools \& Systems. URL: https://www.capterra.com.au/directory/30544/decision-support/software

36. Weistroffer H.R., Smith C.H. and NarulaS.C. Multiple criteria decision support software. Ch 24 in: Figueira J., Greco S. and Ehrgott M. Eds. Multiple Criteria Decision Analysis: State of the Art Surveys Series. N.Y.: Springer, 2005.

37. Buckshaw D. Decision analysis software survey. OR/MS Today. 2010. Vol. 37. \#5. P. 44-53.

38. Каденко С.В., Циганок В.В. Визначення відносної компетентності експертів під час агрегації парних порівнянь. Реєстрація, зберігання і оброб. даних. 2017. Т. 19. № 2. С. 69-83. https://doi.org/10.35681/1560-9189.2017.19.2.126533.

39. Каденко С.В. Проблеми представлення експертних даних у системах підтримки прийняття рішень. Реєстрація, зберігання і оброб. даних. 2016. Т. 18. № 3. С. 67-74. https://doi.org/ 10.35681/1560-9189.2016.18.3.101222 
40. Miller G.A. The Magical Number Seven, Plus or Minus Two. The Psychological Review. 1956. Vol. 63. P. 81-97.

41. Wedley William C. Fewer Comparisons - Efficiency via Sufficient Redundancy. Proceedings of the 10th International Symposium for the Analytic Hierarchy Process - Pittsburgh, PA, July 30 August 3, 2009. URL: http://www.isahp.org/2009Proceedings/Final_Papers/94_Wedley_Fewer_ Comparisons_REV_FIN.pdf

42. Андрійчук О.В. Підвищення достовірності експертних оцінок в системах підтримки прийняття рішень. Реєстрація, зберігання і обробка даних: зб. наук. праць за матеріалами Щорічної підсумкової наукової конференції 26-27 травня 2016 року / НАН України. Інститут проблем реєстрації інформації. Київ: ІПРІ НАН України, 2016. С. 124-126.

43. Tsyganok V., Kadenko S., and Andriichuk O. Hybrid Decision Support Methodology Based on Objective and Expert Data. 2020 IEEE 11 th International Conference on Dependable Systems, Services and Technologies (DESSERT). Kyiv, Ukraine, 2020. P. 265-271.

Надійшла до редакції 04.08.2020 